\title{
Asset Revaluation and the Existential Politics of Climate Change
}

\author{
Jeff D. Colgan ๑, Jessica F. Green, ๑ and Thomas N. Hale $\odot$
}

\begin{abstract}
Whereas scholars have typically modeled climate change as a global collective action challenge, we offer a dynamic theory of climate politics based on the present and future revaluation of assets. Climate politics can be understood as a contest between owners of assets that accelerate climate change, such as fossil fuel plants, and owners of assets vulnerable to climate change, such as coastal property. To date, obstruction by "climate-forcing" asset holders has been a large barrier to effective climate policy. But as climate change and decarbonization policies proceed, holders of both climate-forcing and "climate-vulnerable" assets stand to lose some or even all of their assets' value over time, and with them, the basis of their political power. This dynamic contest between opposing interests is likely to intensify in many sites of political contestation, from the subnational to transnational levels. As it does so, climate politics will become increasingly existential, potentially reshaping political alignments within and across countries. Such shifts may further undermine the Liberal International Order (LIO); as countries develop pro-climate policies at different speeds and magnitudes, they will have incentives to diverge from existing arrangements over trade and economic integration.
\end{abstract}

For the last three decades, international relations (IR) theory has presented the politics of climate change as a collective action problem, relying on models of strategic interaction to explain the presence or absence of international cooperation. We suggest a different approach. We offer a dynamic theory of climate change politics based on the present and future revaluation of assets. We use "assets" as a broad category that includes all inputs to production and sources of material wealth: capital, labor, and natural endowments. We argue that climate change, along with decarbonization policies to mitigate it, will trigger a profound and uneven process of economic revaluation of these assets. That revaluation will ultimately render certain assets valueless, creating a stark distributional struggle, which we term "existential politics." Our aim is to develop a parsimonious political-economic model of the role of asset revaluation on climate politics. It serves as a materialist conceptual scaffolding upon which scholars can add ideational variables to explain climate politics.

This reframing is important for three reasons. First, the traditional thinking overemphasizes free riding by viewing climate change as a static collective action problem among states. It is increasingly challenged by empirical accounts of state behavior, and by the proliferation of action on climate change even in the face of 
free riding. ${ }^{1}$ Conversely, it underemphasizes distributional struggles, particularly those in domestic politics. We emphasize the dynamic nature of distributional conflict: decisions made during one time period affect the preferences, resources, and political power of actors in subsequent time periods.

Second, the politics of asset revaluation are central to understanding the interests and contestation around climate change. Climate change and climate policy are altering the value of assets, from real estate and power plants to the labor of fossil fuel workers. This process generates increasingly contentious political battles over which assets, professions, and communities will retain value or even survive at all. As climate politics becomes "existential" in this way, obstructionism emerges as a key barrier to effective climate policy.

We distinguish between two ideal-typical groups: holders of climate-forcing assets (CFAs) (for example, oil fields, beef farms) and holders of climate-vulnerable assets (CVAs) (for example, coastal property, fisheries). As climate change proceeds, and steps to address it unfold, they alter the value of these assets, and thus, over time, alter the balance of political power between their holders. The theory offers implications for how and when these interests will mobilize for or against climate policy at different scales. The domestic distribution of CFAs and CVAs helps determine what subnational and national climate policies will look like. And the distribution of these assets across nations explains the dynamics of climate governance at the international level.

Third, our theory of asset revaluation highlights a particular threat to the Liberal International Order (LIO) not commonly explored in the IR literature. The variation in climate and industrial policies across nations will affect the costs of exports and imports, incentivizing nations to place new restrictions on trade or other economic linkages. This threat is distinct from those commonly associated with climate change, such as increased risk of conflict, mass migration, or economic crises. ${ }^{2}$ We view current plans to introduce carbon border adjustment mechanisms, which would apply tariffs to certain goods from countries that do not have pro-climate policies, as an early indicator of the tensions that we expect to grow between climate politics and the LIO. ${ }^{3}$ To the extent that such measures proceed heterogeneously across countries, they will disrupt the LIO's principle of economic openness.

Our argument also challenges the implicit normative assumption underpinning much of this special issue: that the LIO as it has existed should be preserved. Weakening the LIO creates risks, of course. Yet with regard to climate change, the preservation of the status quo will likely mean catastrophe. ${ }^{4}$

1. See Aklin and Mildenberger 2020; Hale 2020.

2. See Busby 2018; Koubi et al. 2018; Mach et al. 2019; World Bank 2018.

3. Recognizing the multiple meanings of the LIO identified in the Lake, Martin, and Risse (2021) introduction to this issue, we emphasize here the LIO's distinctive commitment to economic openness, as compared with the interwar period.

4. Wainwright and Mann 2018. 
Climate change is an unprecedented phenomenon, but our focus on revaluation allows for historical comparisons. ${ }^{5}$ For example, as norms and laws changed in the eighteenth and nineteenth centuries to prohibit the slave trade, and eventually, slavery itself, the value of slaves as an asset declined toward zero. Slave owners benefited materially from slaves' labor, but this practice weighed heavily on the conscience of abolitionists. In Britain, Parliament compensated slave owners when it abolished slavery, while in the United States bargaining failures led to a civil war (although compensation occurred in slave-holding states that remained loyal to the Union).

Certain features of this history are analogous to climate change. For example, the utility that assets provide to actors can be material or ideational, and the same asset can generate positive utility for some actors and negative utility for others. Preference intensity is affected by an actor's discount rate (how they value future use of an asset) and the replaceability of an asset. Compensation is sometimes possible, but bargaining can be fraught. Although only an analogy, these features suggest the utility of a focus on asset revaluation. We return to this analogy later.

\section{How to Conceptualize Climate Politics}

Climate change is already remaking our world. Average global temperatures have risen $1{ }^{\circ} \mathrm{C}$ since the Industrial Revolution, and climate change has already increased the size and severity of hurricanes, droughts, fires, and floods around the world. It is a threat multiplier, increasing the likelihood and severity of a variety of social and economic ills, including armed violence in poor states. ${ }^{6}$ The Intergovernmental Panel on Climate Change reports that if emissions continue unchecked, we are very likely to blow through the aspirational target set by the Paris Agreement of limiting warming to $1.5^{\circ} \mathrm{C}$ by 2040 , and perhaps sooner. ${ }^{7}$

Many countries and other actors have pledged ambitious goals, but the reality is that few major emitters are yet on track to deliver reductions commensurate with the goals of the Paris Agreement. Global emissions must halve in the next decade to retain a 50 percent chance of limiting warming to $1.5^{\circ} \mathrm{C}$ in this century. ${ }^{8}$ Yet those emissions were still increasing through 2018, and the pause in emissions growth since then is almost certainly caused by the COVID-19 outbreak. Nor are rising global emissions simply caused by laggards like the United States. At least prior to the COVID-19 outbreak in 2020, China's emissions continued to grow faster than the global average, despite its climate commitments.

5. See Beinhocker 2019; Christopher Hayes, "The New Abolitionism," The Nation, 22 April 2014. Available at <https://www.thenation.com/article/archive/new-abolitionism/>. Accessed 23 September 2020.

6. Mach et al 2019

7. Intergovernmental Panel on Climate Change 2018

8. See Ibid.; Global Carbon Project 2019. 
Therefore, the climate challenge is real. We focus on the politics of mitigation, as opposed to other responses to climate change such as adaptation or geoengineering. Political contestation around these strategies could have parallels to the politics of mitigation that we analyze, but we do not develop those parallels here.

The focus on climate multilateralism from the 1992 Rio Summit to the 2015 Paris Agreement has emphasized the collective action problem of mitigation. According to this view, free riding is the key political challenge. ${ }^{9}$ This account overlooks critical features of the problem. ${ }^{10}$ Many states are defying the static logic of collective action, and instead are choosing to enact pro-climate policies such as carbon pricing or regulations that restrict emissions. ${ }^{11}$ These actions suggest that we have underestimated three factors in climate politics. First, the key driver of climate politics is domestic politics: politicians are responding to the demands of their constituents, many of whom want emissions reductions regardless of what other countries are doing. Second, because domestic politics are so salient, the distribution of power and interests within nations, and the mediating effect of domestic institutions, are key. ${ }^{12}$ The unitary-actor assumption that underpins many collective action models of climate politics leads to significant inaccuracies. And third, strategic actors may recognize the climate challenge as dynamic, in which actions taken in the present can affect preferences and the feasibility of actions in the future. Therefore, first movers may reap benefits from taking early action, ${ }^{13}$ and unilateral emissions reductions can have demonstration effects, providing incentives to actors in other countries to make reductions of their own.

Even so, scholars have produced much valuable research on the institutional landscape of climate cooperation, mostly outside of mainstream IR. ${ }^{14}$ In particular, they have emphasized the role of nontraditional institutional forms in promoting cooperation, such as public-private partnerships, climate experiments, and transnational actors. ${ }^{15}$ Other work has explicitly engaged with political economy, but from the perspective of critical theory. ${ }^{16}$ We build on this work by integrating it with a dynamic, political-economy approach.

In other issue areas, such as trade or finance, scholars have long recognized the importance of distributional politics, dynamics, and institutions. They showed that domestic actors' anticipation of distributional consequences shape trade and

9. Barrett 2003

10. Aklin and Mildenberger 2020 offer a similar argument to ours in this section. We developed our argument independently and perhaps simultaneously. The next two sections add a focus on asset revaluation not found in Aklin and Mildenberger's paper.

11. Ostrom 2010.

12. See Bernauer 2013; Harrison and Sundstrom 2010; Iacobuta et al. 2018; Lachapelle and Paterson 2013.

13. See Green 2014; Hale 2020.

14. See Andonova and Mitchell 2010; Bernstein and Hoffmann 2019; Hovi, Sprinz, and Underdal 2009; Keohane and Victor 2011. On the paucity of climate research in mainstream IR, see Green and Hale 2017.

15. See Andonova 2017; Bulkeley et al. 2014; Hoffman 2011; Ostrom 2010.

16. See, for example, Newell and Paterson 2010. 
finance policy. ${ }^{17}$ Other research demonstrated that the shadow of the future was essential to understanding the dynamic nature of bargaining problems. ${ }^{18}$ And constructivists illustrated the role of institutions and argumentation for shaping domestic preferences, while others emphasized the role of powerful states in shaping international institutions. ${ }^{19}$ This large body of work provided a powerful foundation for understanding the international political economy (IPE); our asset revaluation model shows how climate change fits readily into this IR tradition.

Yet, perhaps because the logic of collective action seemed sufficient to explain policy failures on climate change, scholars have done little to apply the knowledge of distributional politics, dynamics, and domestic institutions to climate change until very recently. We suggest doing so, putting domestic political dynamics at the center. ${ }^{20}$ In contrast to early work that looked at how the shadow of the future affected international bargaining, we focus on how policy choices iteratively affect the size of economic interests that underpin domestic politics. ${ }^{21}$

We concur with the issue's introduction, which notes that large parts of IR theory have "minimized the distributional consequences of orders." 22 Climate change is a distributional problem unprecedented in scale, not only among states, but also within them. Scholars have not paid sufficient attention to obstructionist interest groups who seek to forestall the massive financial and political losses that would result from pro-climate policies, at multiple levels of governance. As such, they work against climate policy regardless of any net societal benefits. For example, one analyst writing in the Financial Times, argued that "favoring unconventional [i.e., renewable] energy will destroy some substantial part of the economic value of the pre-existing energy-using and producing stock of physical and human capital. Earthquakes cannot yield economic benefits; the same is true for policies that wiped out the value of significant parts of the economy." 23 The analyst's opposition to decarbonization is explicitly based on asset revaluation concerns.

Examples of obstructionist lobbying abound. For example, fossil fuel interests devote sizeable sums to climate-related lobbying. The largest five private oil companies (BP, Shell, ExxonMobil, Chevron, and Total) spend more than USD 200 million

17. See Milner 1997; Frieden 1994; Milner and Tingley 2011; Rickard 2018; Goldstein and Gulotty 2021.

18. See Axelrod 1981; Fearon 1998.

19. See Drezner 2003; Martin 1992; Risse 2000.

20. For an early example, see Victor 2011.

21. Increasingly, scholars are attentive to how, over time, both actors' preferences regarding climate policy and their relative power can shift. See, for example, Bernstein and Hoffmann 2019; Hale 2020; Farmer et al. 2019; Pahle et al. 2018.

22. Lake, Martin, and Risse 2021.

23. Benjamin Zycher, "Can We Tackle Both Climate Change and COVID-19 Recovery?" Financial Times, 7 May 2020. Available at <https://www.ft.com/content/9e832c8a-8961-11ea-a109-483c62d17528>. Accessed 23 September 2020. 
per year on such lobbying. ${ }^{24}$ This behavior mirrors well-documented obstructionist strategies for other environmental and health issues ranging from tobacco to seat belts. ${ }^{25}$ Similarly, electric utilities in the United States have fought hard to reduce the ability of homeowners with solar installations to sell their electricity back to the grid. ${ }^{26}$ Obstructionism also provides a plausible explanation for state behavior that conventional theories might interpret as free riding. For example, Saudi Arabia has worked tirelessly to undermine the Intergovernmental Panel on Climate Change report that establishes the scientific basis for limiting warming to $1.5^{\circ} \mathrm{C} .^{27}$ Rather than free riding, this behavior is better understood as an attempt to block any efforts by anyone at all (that is, obstructionism), because those efforts would reduce the value of Saudi Arabia's main export.

Conventional bargaining models are useful in understanding the role of such obstructionists, but the solutions they suggest have limited application to climate. ${ }^{28}$ On the one hand, bargaining theory offers insights like credible commitment problems: if emitters are offered a deal to stop polluting now, but believe that they could get a better deal in the future, they have an incentive to refuse. On the other hand, this same dynamic points to the limits of bargaining theory because it offers so little insight on the conditions under which actors' preferences change, and how that affects political outcomes. Further, unlike international trade, for example, reciprocity is not a key feature of a potential climate bargain because climate benefits accrue globally, not dyadically. In combination with other challenges, such as the difficulty of large interstate side payments, the magnitude of domestic side payments, and the infeasibility of intergenerational distribution, conventional bargaining theory has been less successful when applied to climate change. The empirical results reflect these difficulties: whereas international trade negotiators have overcome various bargaining problems, climate change negotiators have not had similar success.

In sum, insufficient attention has been paid to the compensation problem within countries; for example, offering payments to fossil fuel owners in exchange for their support for progressive climate policies. ${ }^{29}$ Environmentalists have only recently focused on the compensation problem, or what is now called "just transition." Dismantling obstructionism is important not only for domestic politics but also for prospects for international cooperation because domestic interest groups shape national preferences. ${ }^{30}$

24. Sandra Laville, "Top Oil Firms Spending Millions Lobbying to Block Climate Change Policies, Says Report," The Guardian, 21 March 2019. Available at <https://www.theguardian.com/business/2019/mar/ 22/top-oil-firms-spending-millions-lobbying-to-block-climate-change-policies-says-report> Accessed 21 May 2019.

25. Oreskes and Conway 2011.

26. Breetz, Mildenberger, and Stokes 2018.

27. Intergovernmental Panel on Climate Change 2018.

28. See Fearon 1998; Lake and Powell 1999.

29. Some attention has been paid to the international dimension of the compensation problem, in the form of programs such as the Clean Development Mechanism (CDM) and the climate finance obligations of the Paris Agreement. Yet these efforts are relatively small and insignificant. Wara 2007.

30. See Meckling et al. 2015; Milner 1997. 
Persistent obstructionism is a symptom of what we term existential politics. We expect a shift from "normal" distributional politics to existential politics as the negative effects of climate change become more pronounced, and decarbonization efforts intensify. Distributional politics is a broad category, over "who gets what." To define existential politics, we build off the commonsense notion that an existential threat means that something important could be eliminated. Consequently, existential politics is a strict subset: it is the type of distributional politics that involves (1) something of central importance to a given actor being at stake and (2) the prospect of its total elimination. We illustrate that point in Figure 1.

Climate change and decarbonization policies raise the prospect of extinction for CVAs and CFAs, respectively. It contrasts with other kinds of distributional politics, which involve adjustments on the margins (for example, falling wages) or through which a substitutable good is lost (for example, high trade tariffs making avocados prohibitively expensive, leading to consumers buying something else). Existential politics often means that there is a contest over whose way of life gets to survive. Should we have Miami Beach and the Marshall Islands, or should we have coal miners, ExxonMobil, and Chevron ${ }^{31}$ This extreme form of distributional politics exists in other areas of international political economy (for example, a trade agreement or technological change can wipe out an uncompetitive industry), but we suggest that the scale of climate change will make existential politics the increasingly dominant lens through which to understand climate politics.

\section{A Dynamic Theory of Asset Revaluation}

We offer a new approach to climate politics that focuses on changes in distributional conflict as climate change and decarbonization revalue assets. ${ }^{32}$ Our basic contention is that as distributional conflicts expand and intensify, climate politics will become existential. Different interests will not only fight over who gets what but also over whose way of life survives. In turn, this will influence the shape and nature of those conflicts.

The theory is dynamic; over time, actors' interests, power, and their willingness to mobilize will change with the valuation of their assets. This iterative process will be shaped by feedbacks and mediated through institutions and culture, which condition whether and how interests become mobilized. We articulate our model in general terms, but illustrate it principally, although not exclusively, with reference to national polities. These domestic dynamics then shape the likelihood of successful agreement among states at the international level. ${ }^{33}$

31. On climate change knock-on effects affecting the Marshall Islands, see Colgan 2018.

32. There are also nonmaterial explanations of obstructionism, but we focus on material concerns as a first-order approximation of motivation for most emissions.

33. Putnam 1988. 


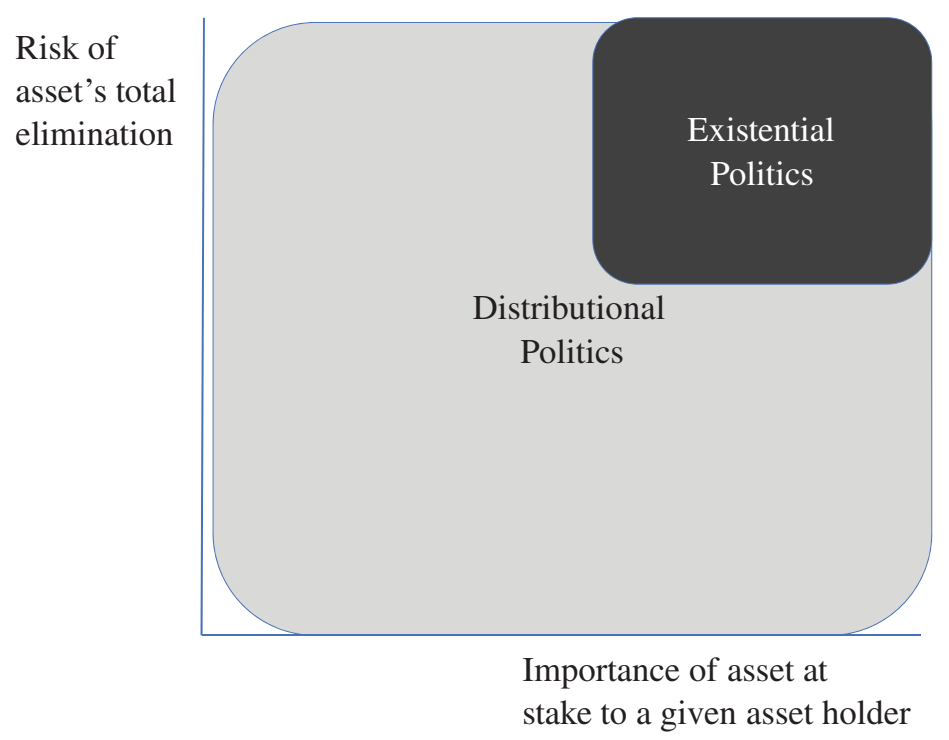

FIGURE 1. Distributional and existential politics

The model makes two conceptual steps. First, we sort actors into two ideal-typical groups, those holding CFAs (for example, oil fields, cattle farms, car plants) and those holding CVAs (for example, coastal property, farms in arid areas). Actors may of course hold both CFAs and CVAs (for example, an oil rig in a hurricane zone, or many investment funds), and some actors can benefit rather than suffer from either climate change or decarbonization. ${ }^{34} \mathrm{We}$ abstract from these complexities for now by focusing on which asset class dominates an actor's preferences.

As in many political economy models, asset specificity is important for how individual actors behave. For example, CFA or CVA holders might change their position by trading one set of assets for another. Yet this possibility does not fundamentally change the political dynamics that we highlight. An owner of a coal mine might be able to sell the asset to someone else without accepting a loss (that is, at a price unaffected by climate policy) but that simply changes the identity of the asset holder, while leaving in place the fact that there is someone with a vested interest in that CFA. Alternatively, an asset holder might be unable to sell the asset without taking a loss, possibly as large as the asset's entire value. Saudi Arabia, for example, would probably find it hard to completely exit the oil business without accepting a major loss in the value of its oil reserves. Similarly, a coal

34. Behavioral science leads us to generally expect "losers" to respond more stridently than "winners," but we cannot discount the potential of future winners to mobilize to secure larger gains. See Meckling et al. 2015 . 
miner might find it difficult to retrain to work in the solar industry, and may have to take a lower-paying job. In these cases, the asset holders have limited exit options and will be all the more wedded to the assets that they hold. Either way, there will be some actors who own CFA or CVA assets, some of very limited fungibility, which will determine their economic interests.

We recognize that these groups are not neat categories. Many asset owners will hold both CFAs and CVAs. We therefore conceptualize asset holders on a spectrum, based on the ratio of their asset holdings and the ease (or cost) with which they can transform their assets. The spectrum runs from pure CVA holders with no viable exit option without experiencing a major loss, to more flexible asset holders, to pure, noexit CFA holders. For example, oil companies are obvious CFA holders with very high exit costs because their capital is tied to oil reserves, drilling technology, refineries, and other assets that can derive value from only fossil fuel production. Insurance companies, in turn, are CVA holders who will find it difficult to avoid climate impacts, serving as "the economy's shock absorber." ${ }^{35}$ As extreme weather events become more frequent, insurance companies are paying out more, and risks will only increase. As one insurance executive noted, "whereas "a $\left[2^{\circ} \mathrm{C}\right]$ world might be insurable, a $\left[4^{\circ} \mathrm{C}\right]$ world certainly would not be." ${ }^{36}$ Between these two poles we could place many financial firms, which typically own mixes of CFAs and CVAs, and can shift between the two as quickly as market liquidity will allow. Climate politics are fundamentally shaped by a contest between the asset holders on this spectrum as they struggle to influence policymakers to favor policies that defend their assets.

The second conceptual step is to assume that as climate change and decarbonization policies develop, they will alter the value of assets over time. The more CFAs there are in the world, the more climate change will unfold, reducing the value of CVAs. In turn, the more that CVAs are protected via mitigation measures, the less valuable CFAs will tend to become. CFA and CVA holders both seek to maintain or increase their assets' value, which means devaluing the other asset class; thus, contestation occurs around policies that alter the value of each. We also assume that asset holders' power is a function of their holdings, with more valuable assets meaning more power. This can be interpreted as both instrumental power (they can use their material resources to lobby) and structural power (policymakers are loath to harm important economic assets even if asset holders do not proactively defend them).

Over time, pro-mitigation policies reduce the value of CFAs relative to CVAs, whereas blocking mitigation policies has the opposite effect. Past policies can therefore affect the future balance of political power. ${ }^{37}$ Should pro-climate policies remain dominant for an extended period, they may reduce CFAs so sharply that anti-climate

35. Adam Tooze, "Why Central Banks Need to Step Up on Global Warming," Foreign Policy, 20 July 2019. Available at <https://foreignpolicy.com/2019/07/20/why-central-banks-need-to-step-up-on-globalwarming/>. Accessed 23 September 2020.

36. As quoted in ibid.

37. This pattern is not unique to climate politics; for example, see Peters 2017 on trade and migration politics. 
interests lose all political power, or vice versa. In such cases, climate policy will be self-reinforcing. Alternatively, if neither side gains dominance, policy might fluctuate. Thus, asset revaluation can provide a dynamic explanation for actors' interests and the conflicts among them.

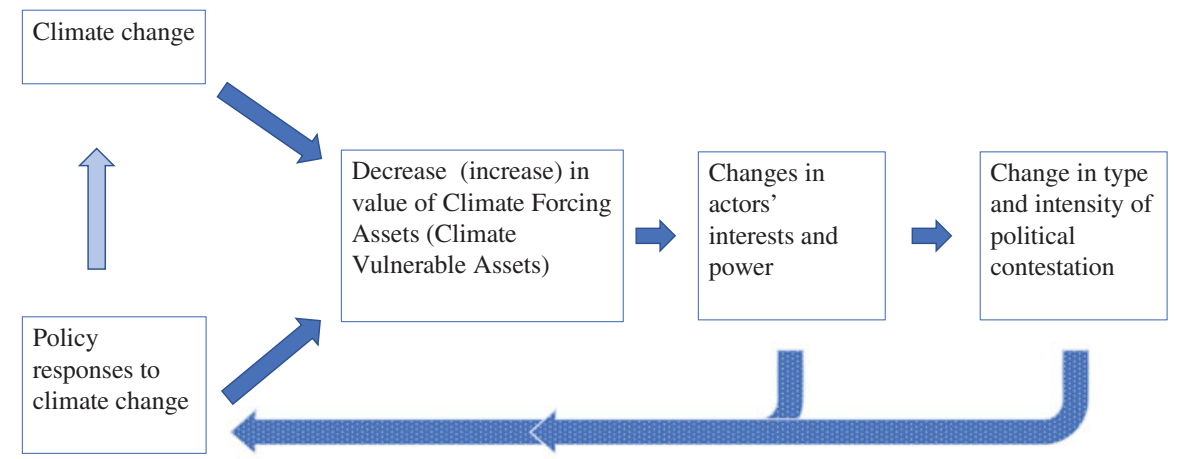

FIGURE 2. A dynamic theory of asset revaluation

Figure 2 illustrates the logic of our theory of asset revaluation. Overall, we expect the change in intensity and type of political contestation to result in more existential politics. Domestically, the intensity of conflicts will vary across countries. For example, Saudi Arabia remains wholly committed to oil production, and therefore is less likely to have intense political contestation than, say, Canada. However, variable regulation across nations will affect even nations with less intense conflict, through international supply chains.

Although we focus on material factors, climate politics is not merely about economic interests. We expect the balance of CFA and CVA to be a good first approximation of whether pro-climate policies will be adopted or not, but it will certainly not explain every case because institutional and ideational factors will obviously matter. Economic revaluation lays the foundation for actors' interests, but their actual preferences are determined through a complex social process that we do not model here. Norway, for example, is an oil-rich economy, but has a cultural and structural position that makes it relatively favorable to pro-climate policies (as well as a strategy of converting its oil wealth into a more flexible sovereign wealth fund). The process of political contestation will be expressed in domestic politics in ways that are mediated by identity politics, demographics, religion, political institutions, and other non-economic factors. For example, Greta Thunberg and the Fridays for Future Climate Strikes tap into demographic cleavages more closely than into economic cleavages. Such campaigns will not always map cleanly onto actors' asset holdings. Still, national and subnational economic interests underpin the political environment that allows such campaigns to gain resonance.

Climate politics is also driven by communities and their cultures, rather than by homo economicus: individuals who are independent from one another. Consider 
Belchatow, Poland, a coal-mining town with power plants that generate 20 percent of Poland's electricity. ${ }^{38}$ The company that runs the coal mine and electricity plants employs 8,000 people directly, and the rest of the city's 60,000 residents are indirectly dependent. Yet coal is not only an economic interest-it is also a cultural touchstone. The city venerates St. Barbara, the miners' saint. The city's logo is an "on" button. Even for residents who are not directly employed by it, coal is part of the community's way of life. Pro-climate policies are therefore an existential threat to this community. We should not expect the political dispute to be made in the cold language of pure economic interests. Instead, there might be a combination of climate denialism, patriotism, populism, and other factors as actors defend CFA interests.

Consequently, we see a two-stage process: in the first stage, economic interests that depend on the asset base; and in the second stage, political contestation shaped by additional factors. Where CFA or CVA interests have overwhelming strength, the second stage will be less important but in many cases, the non-economic factors will play an important role in shaping how and to what extent politics support proclimate policies. Our assumption remains, however, that the distribution of asset value represents a critical driver in climate politics.

\section{Asset Revaluation and the Shift Toward Existential Politics}

The nature of political contestation is determined by how and when interests become mobilized. To illustrate, we build on James Q. Wilson's book, The Politics of Regulation, which explains how the concentration or dispersion of the costs and benefits of regulation affect the politics surrounding it. This framework is tailored to explain democratic politics at the national and subnational level, but an authoritarian illustration could also be derived from the asset revaluation framework. Either way, these domestic political dynamics play a crucial role at the international level through the logic of two-level games. ${ }^{39}$ Wilson identifies four ideal types (see Table 1). Following Mancur Olson, Wilson argued that dispersed interests will struggle to organize, and therefore have limited influence on regulatory policy. ${ }^{40}$ Policy changes are relatively difficult when they are in favor of dispersed interests, or against concentrated interests.

In Wilson's treatment, the concentration or dispersion of interests were exogenous to the problem at hand; he did not explicitly consider whether and how interests might change over time, thus affecting the politics. For example, the framework describes issues such as clean air as "entrepreneurial," because they require some catalytic actor such as nongovernmental organizations (NGOs) to organize diffuse interests among

38. Charlemagne, "Environmentalism Is Emerging as Europe's New Culture War," The Economist, 29 June 2019. Available at <https://www.economist.com/europe/2019/06/29/environmentalism-is-emergingas-europes-new-culture-war>. Accessed 4 June 2020.

39. Putnam 1988.

40. Olson 1971. 
the population in order for them to have a political effect. Wilson did not expect shifts from one kind of politics to another. But as others have noted, the way a problem is defined, including what interests are affected, can change over time. Our focus on assets, whose value is inherently mutable, emphasizes this dynamic element. ${ }^{41}$

TABLE 1. Concentration of costs and benefits of regulation shape democratic politics

\begin{tabular}{lll}
\hline Costs / Benefits & Concentrated & Dispersed \\
\hline Concentrated & Interest group politics; & Client politics; \\
& Example: Anti-trust & Example: Agricultural subsidies \\
Dispersed & Entrepreneurial politics; & Majoritarian politics; \\
& Example: Clean air & Example: Labor regulation \\
\hline
\end{tabular}

Source: Adapted from Wilson 1980.

To see how changes in asset value drive both increasing concentration and dispersion of interests, consider the development of climate politics in most industrialized countries. From the 1980s to the mid-1990s, climate change politics fell largely into two categories: client politics and entrepreneurial politics. The primary actors pushing for greenhouse gas (GHG)-reducing policies were environmentalists rather than CVA holders. ${ }^{42}$ They engaged in entrepreneurial politics. CVA holders remained generally unaware of the distant and uncertain potential threats to their assets, and therefore remained largely unorganized. ${ }^{43}$ CFA holders, by contrast, were concentrated and well organized, enjoying substantial, concrete benefits from the status quo. They engaged, virtually unopposed, in client politics, reaping the benefits of policies whose costs were dispersed across the public at large, such as myriad production subsidies. In this early period, CFA holders did not bother to invest significant effort in opposing environmentalists, relying instead on their vast structural power and significance for the economy. Contestation was minimal. Instead, CFA holders were content to cast doubt on the certainty of climate science to prevent CVA holders from realizing the threat that they faced, and mobilizing. ${ }^{44}$

The next period began (roughly, in the late 1990s) as demands for pro-climate policy rose. Under those conditions, CFA holders were increasingly threatened. The costs of climate policy also began to concentrate. Specific sectors and communities (for example, coal miners, flood-prone areas) began to feel acute costs. In response to these threats, CFA holders have started to mobilize actively. For example, Exxon has recently backed a nominal carbon tax as a way to forestall

41. Lowi 1964.

42. For a history of non-state actors in the climate regime, see Green 2014; Hadden 2015.

43. It is important to note here that marginalized communities have possessed CVAs and been aware of this problem, but have been largely disenfranchised from political processes.

44. Oreskes and Conway 2011. 
more onerous costs and regulations. ${ }^{45}$ Electric utilities continue to lobby aggressively against net metering and other efforts to expand the use of solar power. ${ }^{46} \mathrm{By}$ one estimate, achieving the $2^{\circ} \mathrm{C}$ target of the Paris Agreement risks generating USD 4 trillion in "stranded assets" (investments that have lost economic value) among the fossil fuel industry alone. ${ }^{47}$

At the same time, CVA holders have gradually emerged as a potential rival source of policy preferences, as the effects of climate change become evident. This is demonstrated by the mobilization of institutional investors who seek to minimize climate risks that may devalue their holdings. ${ }^{48}$ In 2017, institutional investors holding USD 22 trillion in assets wrote a letter to the G20 demanding continued support for the Paris Agreement, stating "as long-term institutional investors, we believe that the mitigation of climate change is essential for the safeguarding of our investments." 49 Individual firms have also begun to recognize the vulnerability of their assets. Unilever has begun estimating the costs of supply chain disruptions caused by the effects of climate change; in 2015, the figure was an estimated EUR 300 million per year. ${ }^{50}$ This increasing awareness suggests the potential for the private sector, especially the financial industry, to emerge as a strong interest group advocating for more aggressive climate policy.

In this way, asset revaluation is changing the balance of power and the concentration of interests. CVA holders are mobilizing because of visible climate change. CFA holders are becoming more threatened because of the pressure to decarbonize. Increasingly, the economy can be sorted into these two groups based on the mix of assets that they hold and the degree to which they can be substituted. This shifts sleepy "client politics" or "entrepreneurial politics" to hard-fought "interest group politics." It is important to note that the particular policies that each group (CVA versus CFA) endorses will not always be straightforward: CFA holders might endorse green policies when it puts their commercial rivals at a disadvantage, for example. ${ }^{51}$

Additionally, CVA and CFA holders are becoming more numerous, which will likely result in a shift toward majoritarian politics. Whereas CFA holders were previously generally restricted to fossil fuel companies, it is now clear that vast swaths of the economy will have to decarbonize relatively soon. Sectors such as shipping, aviation, and industrial and chemical production can now be considered CFAs. They are increasingly the targets of regulation and will have to figure out how (or

45. Climate Leadership Council 2017.

46. Breetz, Mildenberger, and Stokes 2018; Brulle 2018.

47. Mercure et al. 2018.

48. Hsueh 2019.

49. Global Investor Coalition on Climate Change 2017.

50. Jessica Shankleman, "Unilever Chief: Climate Change is Costing Us $€ 300 \mathrm{~m}$ a Year," BusinessGreen, 30 November 2015. Available at: <https://www.businessgreen.com/news/2436836/unilever-chief-climatechange-is-costing-us-eur300m-a-year>. Accessed 23 September 2020.

51. That is, preferences are not only a function of assets held, but also of an actor's position relative to competitors. See Kennard 2020. 
whether) to protect the value of their assets in a carbon-constrained world. Thus, decarbonization and climate change are not only deepening the concentration of interests among CFA and CVA holders, they are also "broadening" the dispersion of those interests.

Similarly, the large numbers of people who live near coasts, or areas affected by forest fires, mudslides, and droughts, are examples of the growing number of CVA holders. Their assets are directly or indirectly affected by climate change. Future generations are increasingly aware of their status as CVA holders, as evidenced by the growing youth movement around school strikes for climate. In the legal realm, there are an increasing number of lawsuits in which future generations and other affected groups are compelling states to increase their climate policies, such as the 2019 Urgenda case in the Netherlands. ${ }^{52}$ For example, associations representing California crab fishermen filed a suit in November 2018 against thirty fossil fuel companies to make them pay for damages to California's fisheries that were the result of climate change. A month later, the elite ski resort in Whistler, British Columbia, demanded compensation from the oil sector in Alberta, Canada. ${ }^{53}$ Additional disputes or lawsuits exist in California, Washington, Rhode Island, New York, and in France and the European Union. ${ }^{54}$

As the effects of climate change become more frequent and intense, we can expect a shift, not only to majoritarian politics, but also to existential politics. A greater number of actors will be directly, and sometimes gravely, affected by climate change. In turn, the gravity of these effects shifts the policy discussion from extracting concessions - an issue of distribution-to ensuring survival. The politics of mitigation thus seems primed to become increasingly existential.

\section{Implications For Mobilization, “Flipping,” and Realignment}

Our theory has implications for political mobilization and interest group realignment. Mobilization is easiest when actors are already organized into a shared institution for other reasons. They can then readily translate shared interests into political activity. CFAs were the first to mobilize and have shaped institutions accordingly. CVA holders have only begun to do so. ${ }^{55}$ Consequently, we see CVA holders mobilizing first where they already have institutions that bring them together around shared interests, such as "front-line" communities located next to power plants, in the Arctic, and near the coast.

But we should not necessarily see interest groups as fixed. The distribution of interests can change when actors switch their policy preferences in response to asset

52. Setzer and Byrnes 2019.

53. Tony Seskus and Kyle Bakx, "Oilpatch Stays Home from BC Conference after Whistler Mayor Calls for Climate-Change Compensation," CBC, 14 December 2018. Available at <https://www.cbc.ca/news/ canada/calgary/whistler-conference-oil-1.4946354> Accessed 23 September 2020.

54. Drugmand 2018.

55. Bernstein and Hoffmann 2019. 
revaluation. Other contributions to this special issue show that deepening economic integration, coupled with the "disembedding" of liberalism, has undermined the political coalitions supporting the LIO. In climate, we cannot yet say how asset revaluation will shift current political cleavages, but instead emphasize its large potential to do so. As noted, nearly all actors-states, subnational jurisdictions, corporations, and sectors-possess some mix of CFAs and CVAs. We should therefore not take policy preferences as given, but rather explore how the dynamics of asset revaluation might change them over time.

Flipping, realignment, and strategic repositioning offer three mechanisms through which political cleavages and the balance of power between them could change. Flipping occurs when an individual actor's asset balance tips from being CFA dominated to being CVA dominated, or vice versa. Realignment, instead, occurs when the balance of power between CFA holders and CVA holders tips from one group to the other in a polity or other collective body. Strategic repositioning occurs when an actor such as a firm decides to change its policy preferences based on its competitive position relative to other firms, perhaps seeing that although climate policy would be costly, it would be more costly for the actor's competitors than for itself. This third mechanism has been explored elsewhere, so here we focus on the first two. ${ }^{56}$

For flipping and realignment, we expect the ratio of CFAs to CVAs and asset specificity to drive changes in policy preferences. All else being equal, actors with more CFAs will resist decarbonization; those with more CVAs will support it. Actors' preferences will change if one class of assets loses value, if firms develop new expectations about the future value of CFAs and CVAs, or if those with less asset specificity divest. For example, whereas car manufacturers have traditionally resisted climate policies, some companies hoping to profit from the shift to electric vehicles now support policies that they used to resist. In this way, flipping at the actor level is essentially a form of Bayesian updating, where those in leadership positions "see the writing on the wall" and adjust their holdings and preferences accordingly.

For collective bodies - for example, states, industry associations-preferences are determined by which group of actors dominates internal decision-making processes. Realignment, therefore, can occur when the strategies of individual asset holders aggregate up to the collective level. If enough individual actors flip from CFAs to CVAs, they may seize the levers of collective decision making. Most straightforwardly, we could imagine polity realignment if CFA interests come to dominate CVA interests, or vice versa. But realignment can occur at other scales as well. We see some preliminary indications of this process: some CVA-holding businesses are breaking from industry groups dominated by CFA holders. A number of large multinational firms, including Pacific Gas and Electric and Exelon, have severed ties with the US Chamber of Commerce, citing its questionable practices on 
climate change. ${ }^{57} \mathrm{~A}$ second way realignment can occur, however, is when the actors that hold particular institutional positions change. For example, if relatively progressive oil companies such as BP and Shell hold the leadership positions at the American Petroleum Institute, it might look quite different than if Exxon and Chevron held them. This could occur because of preference change (if the leadership positions are selected by vote, for example) or for institutional reasons (if the leadership rotates automatically).

Once a collective realignment occurs, it may reinforce individual flipping. For example, a city or province might decide to transition to 100 percent renewable energy, or an industry might phase out fossil-based technologies by shifting toward electric vehicles. In these instances, those making climate-friendly investment decisions effectively outnumber the CFA owners. Affected CFA owners may then adapt, changing their asset holdings. Over time, as CFA holders flip at the individual level, a positive feedback loop could reinforce broader realignment. ${ }^{58}$ Alternatively, CVA owners may choose a different strategy, either exiting the jurisdiction or fighting even harder for their original business strategy.

Climate-induced flipping and realignment may significantly shift climate politics in the coming years. The distribution of CFAs and CVAs does not map cleanly onto existing political cleavages. In many countries, support for environmental policies is associated with left-leaning social and economic views, but this need not be the case in the future. For example, in the United States, the three states with the highest per capita GHG emissions are Wyoming, North Dakota, and West Virginia, respectively. ${ }^{59}$ All three are right-leaning states with major fossil fuel extraction. But this may not always be the case. A decline of the fossil fuel industries would weaken the political power of CFA holders and could shift the state toward more climate-friendly policies.

The potential for sharp realignments highlights how both climate change and responses to it could affect dynamics across multiple scales. From inside firms to across entire economic sectors, from small municipalities to nation-states, climate politics could disrupt even world politics. We turn to this question now.

\section{Implications for the LIO}

The LIO helped create climate change, and now climate change may contribute to its undoing. As this issue's introduction notes, the LIO accelerated economic growth and spread industrialization in the years following 1945. That growth led to vast

57. Kyle Bakz, "Shell Urges Canada's Oil Lobby Group to Support Carbon Tax," CBC, 2 April 2019. Available at <https://www.cbc.ca/news/business/shell-capp-climate-1.5081036> Accessed 23 September 2020 .

58. See Farmer et al. 2019; Hale 2020.

59. Friedrich, Ge, and Tankou 2017. 
greenhouse gas (GHG) emissions, driving climate change. Now climate change threatens the LIO itself.

Climate change creates a dilemma that threatens the foundations of free trade and economic integration. States can respond to climate change with policies on a spectrum ranging from no action to aggressive GHG mitigation, such as high carbon taxes or regulatory bans of certain production methods, which in turn will affect the value of various assets. For example, steel exports become less competitive in nations with hefty carbon prices. Variation in how countries intervene in the economy for and against climate policies will likely increase in the future, affecting whether and how states choose to trade with each other. We consider three possible scenarios for trade.

One possibility is that all states simultaneously adopt very aggressive pro-climate policies. That possibility is so unlikely that we discount it because those policies are likely to be highly costly for most states, especially oil producers. Only under this improbable scenario would we expect economic integration to remain largely unaffected (other than the extent to which climate policies increased the costs of transportation).

Another possibility, which we think would be the most likely, is significant variation in states' climate policies-correlated with the distribution of CFAs and CVAs - which would challenge liberal principles of open markets. Some states would pursue policies to hasten decarbonization (often those with a greater proportion of CVAs), whereas others (those that are CFA heavy) would continue to subsidize fossil fuels or even increase their subsidies as clean alternatives proliferate. That divergence has competitive consequences: progressive policies in one state create an incentive, all else being equal, for GHG-intensive industries to move to other states where climate policies are weaker. Similarly, states with greener economies have a strong incentive to protect their producers against low-cost, dirty imports. Thus, states may move away from the LIO's existing arrangements for global economic integration. ${ }^{60}$ Indeed, many economists who advocate for progressive climate policies suggest that they will necessitate border measures such as green tariffs. ${ }^{61}$ In turn, disputes over "green tariffs," fossil fuel subsidies, carbon taxes, and other policy measures to regulate differences in production methods across countries are likely to intensify as they increasingly affect the competitive advantages of each state. ${ }^{62} \mathrm{~A}$ recent carbon tax proposal in the United States from the Climate Leadership Council, backed by ExxonMobil and other firms, calls for such "border adjustments." 63

62. See Blondeel, Colgan, and Van de Graaf 2019; Mehling et al. 2018; van Asselt 2017.

63. John Schwartz, "Exxon Mobil Lends Its Support to a Carbon Tax Proposal," The New York Times, 20 June 2017. Available at <https://www.nytimes.com/2017/06/20/science/exxon-carbon-tax.html>, accessed 11 October 2018. 
The final possibility is that states' policies to mitigate GHG emissions may be uniformly minimal, and therefore do not disturb the LIO's current arrangements on economic integration. That possibility is real but would represent a failure of the LIO, both economically and politically. Economically, unaddressed climate change will do massive economic damage, creating reduced or negative growth. In turn, economic hardship will make international cooperation harder since distributional disputes become more intense in a shrinking economy. Politically, the continued failure to craft an effective international response to climate change will cost the LIO legitimacy. Indeed, it would be difficult to call the international order "liberal" at all, because the world would look more like a realist alternative in which states hardly cooperate.

The second scenario appears most likely: considerable variation among national climate policies, which will affect openness. The four emitters that are arguably most important-China, the United States, the European Union, and India-are moving in quite different directions on climate policy. Broadly speaking, the European Union is the most progressive on climate policy. Lagging behind the European Union are China and the United States, where most effort is concentrated in subnational units and overall emissions reductions are modest. India continues to mostly prioritize economic development over environmental goals. As contestation over climate policy intensifies, it will increasingly challenge norms and institutions at the economic core of the LIO. ${ }^{64}$

Two emerging issues in the trade regime support our expectation that variation among emitters' climate policies will create tension for the LIO. First, the European Union has recently announced it will impose a "carbon border adjustment mechanism"; essentially, a tariff levied on goods produced in countries where no carbon pricing scheme exists. This helps maintain competitiveness for EU goods, as costs of production rise with more stringent climate policies. And it helps reduce carbon leakage, so that EU-based firms do not simply shift their activities to jurisdictions without carbon pricing. The proposal is a long way from implementation, but other states have already registered their concerns. At the time of writing, the Trump administration is already discussing the possibility of retaliation, even as his Democratic challenger promises a new administration would follow the same path. ${ }^{65}$

The second issue involves violations of the World Trade Organization's (WTO) "national treatment" principle, as governments seek to support renewables. Many of these have been based on "local content" provisions of renewable energy support programs. For example, Ontario, Canada, created a feed-in tariff program for renewables that also included a provision that a share of the technology be produced in the province. ${ }^{66}$ Japan disagreed, arguing that this constituted discrimination

64. Zürn 2018.

65. Gillian Tett, Chris Giles, and James Politi, "US Threatens Retaliation Against EU Over Carbon Tax," Financial Times, 26 January 2020.

66. Stokes 2013. 
against foreign renewable products. The Dispute Settlement Panel sided with Japan. Similar cases around feed-in tariffs have been targeted at producers in the United States, China, the European Union, and India. ${ }^{67}$ This problem will likely resurface as developed nations seek to implement industrial policies to promote decarbonization, as proposed in various plans for a "Green New Deal." The tension between national autonomy to pursue industrial policy to address climate change and the previously agreed-to measures at the WTO could of course be renegotiated, but this would put in play core tenets of the LIO, such as the WTO's national treatment principle.

Recent experience highlights the potential for conflict. In 2012, the European Union announced a plan to require all flights in EU airspace to purchase emissions allowances under its emissions trading scheme. The proposal prompted immediate, vociferous backlash from Russia, India, and China, and almost sparked a trade war. China said that it would refuse to participate in the scheme, and Russia discussed the possibility of retaliation. The conflict was diffused by the agreement to pursue aviation emissions regulation under the auspices of the International Civil Aviation Organization (ICAO), eventually producing the Carbon Offsetting and Reduction Scheme for International Aviation (CORSIA) Agreement.

There are historical parallels as well. As mentioned, the end of slavery demonstrated how asset revaluation can threaten the international order. When the United Kingdom abolished slavery in 1838, well before France, the United States, or other states did, it created heterogeneity in the international order, especially at sea. Although the slave trade was already nominally illegal, some countries were less interested in enforcing that prohibition than others. The United Kingdom chose to use the Royal Navy in the 1840s and 1850s to disrupt the slave trade, at considerable cost to the United Kingdom and to the annoyance of the United States and France. ${ }^{68}$ At that time, therefore, divergence in national practices led to the requirement for international action, which in turn led to frictions between states. A similar dynamic makes climate change a threat to the LIO. Varying levels of obstructionism means that some countries will act unilaterally to reduce emissions whereas others will not. If the former create economic borders against the latter, as seems likely, it will erode the openness that underpins the LIO.

\section{Conclusion}

Climate change is a clear threat to the LIO in either of two probable scenarios. One possibility is that the members of the LIO will do nothing much to mitigate climate change. That would represent a major substantive failure and a blow to the LIO's 
legitimacy. ${ }^{69}$ Alternatively, states might adopt pro-climate policies, but do so unevenly, with some implementing stronger and costlier policies than others. That unevenness would threaten the economic openness of the LIO, as jurisdictions with costlier pro-climate policies face competitive pressures to adopt measures such as border adjustment tariffs. In either scenario, climate politics is important for understanding the LIO's future. The distributional consequences of climate change and decarbonization - and the obstructionist reactions that they generatewill be central.

The lens of asset revaluation helps us analyze these dynamics. Assets will change in value in response to the concrete effects of climate change, and in response to climate policies. Actors will seek to preserve their assets accordingly. Increasingly intense conflicts will arise among a growing number of interest groups over whose assets get preserved. In instances in which assets are central to a way of life, and are at risk of being eliminated, politics will become existential. The existential politics of climate change - its intense political contestation over whose way of life continuesis likely to generate interest group realignment and friction at the international level.

Four key questions stand out for future climate change research. First, how and with what implications will ideology and identity politics move climate politics beyond what we might expect from rationalist analysis based primarily on economic factors? As we have noted, one hypothesis is that, at the existential extremes of distributional politics, such factors are increasingly salient. Additional work on the role of emotions, ideology, and identity is needed to better understand climate politics. Among emotions, discontent and even despair seem insufficient to mobilize groups; rather, anger seems essential. Anger and outrage, for example, appear to be fueling the international climate strikes by school children, which gained momentum in 2019. Ideology and identity are also central to understanding mobilization on climate change. For example, First Nations people in Canada have argued for climate action on the grounds that much of their culture is under threat as Arctic ice recedes.

Second, under what conditions can CVA holders be mobilized and organized politically? In addition to emotions, ideology, and identity, scholars might investigate how key stakeholders and focal points for mobilization vary across nations. Relatedly, what forms of compensation to CFA holders are most likely to be politically acceptable to other stakeholders? We suggest that novel and creative solutions might be necessary, such as the government taking over pension liabilities of dying coal companies, nationalization of utilities, or guaranteed basic income for those who are phased out of the fossil fuel industry and cannot be retrained.

Third, what are the conditions that would promote partisan realignment around the CFA versus CVA axis ? $^{70}$ We have offered some insight into interest group realignment, which might also apply to political parties, but these have an additional level of 
complexity because parties build preference coalitions over multiple issues. In the post-2016 populist moment, partisan identities appear to be somewhat looser in many countries on both sides of the North Atlantic. It is possible that future politics will be defined, in part, by how to respond to the climate challenge. Growing mobilization of CVA holders could substantially disrupt current partisan alignments in multiple countries.

Finally, how will actors favoring different climate strategies compete for the pool of resources for addressing climate change? We emphasize here how actors with CVAs are likely to favor mitigation policies, but they might also pursue three other strategies: adaptation, compensation, or even geo-engineering. ${ }^{71}$ Indeed, the demand for such "defensive" policies rather than for preventive measures such as decarbonization may grow as climate impacts become increasingly existential and immediate. We observe such a shift in how new climate response strategies have been introduced into the United Nations Framework Convention on Climate Change (UNFCCC) process over time. Although the initial focus was squarely on mitigation, countries with CVA assets increasingly pushed adaptation as a core focus of the international regime. At present, the growing UNFCCC negotiations over "loss and damage" illustrate rising attention to compensation. ${ }^{72}$ Large emitters have blocked compensation claims in the UNFCCC, but such cases are already being brought and won in national and international courts. ${ }^{73}$ Understanding the mix of strategies that actors pursue is likely to be essential for explaining how the LIO responds to the climate challenge.

\section{References}

Aklin, Michaël, and Matto Mildenberger. 2020. Prisoners of the Wrong Dilemma: Why Distributive Conflict, Not Collective Action, Characterizes the Politics of Climate Change. Global Environmental Politics 20 (4):4-27.

Andonova, Liliana. 2017. Governance Entrepreneurs: International Organizations and the Rise of Global Public-Private Partnerships. Cambridge University Press.

Andonova, Liliana B., and Ronald B. Mitchell. 2010. The Rescaling of Global Environmental Politics. Annual Review of Environment and Resources 35 (1):255-82.

Axelrod, Robert. 1981. The Emergence of Cooperation Among Egoists. American Political Science Review 75 (2):306-18.

Barrett, Scott. 2003. Environment and Statecraft. Oxford University Press.

Beinhocker, Eric. 2019. I Am a Carbon Abolitionist. Democracy, 24 June. Available at <https://democracyjournal.org/arguments/i-am-a-carbon-abolitionist/>

Bernauer, Thomas. 2013. Climate Change Politics. Annual Review of Political Science (16):421-48.

71. Jinnah, Nicholson, and Flegal 2018.

72. Calliari 2018.

73. Setzer and Byrnes 2019. 
Bernstein, Steven, and Matthew Hoffmann. 2019. Climate Politics, Metaphors and the Fractal Carbon Trap. Nature Climate Change 9:919-25.

Blondeel, Mathieu, Jeff D. Colgan, and Thijs Van de Graaf. 2019. What Drives Norm Success? Evidence from Anti-Fossil Fuel Campaigns. Global Environmental Politics 19 (4):63-84.

Breetz, Hanna, Matto Mildenberger, and Leah Stokes. 2018. The Political Logics of Clean Energy Transitions. Business and Politics 20 (4):492-522.

Brulle, Robert J. 2018. The Climate Lobby: A Sectoral Analysis of Lobbying Spending on Climate Change in the USA, 2000 to 2016. Climatic Change 149:289-303.

Bulkeley, Harriet, Liliana Andonova, Michele Betsill, Daniel Compagnon, Thomas Hale, Matthew Hoffmann, Peter Newell, Matthew Paterson, Charles Roger, and Stacy VanDeveer. 2014. Transnational Climate Change Governance. Cambridge University Press.

Busby, Joshua. 2018. Warming World: Why Climate Change Matters More Than Anything Else, Foreign Affairs July/August. Available at <https://www.foreignaffairs.com/articles/2018-06-14/warming-world>.

Calliari, Elisa. 2018. Loss and Damage: A Critical Discourse Analysis of Parties' Positions in Climate Change Negotiations. Journal of Risk Research 21 (6):725-47.

Climate Leadership Council. 2017. The Conservative Case for Carbon Dividends. Available at $<$ https:// www.clcouncil.org/media/2017/03/The-Conservative-Case-for-Carbon-Dividends.pdf $>$. Accessed 4 June 2020.

Colgan, Jeff D. 2018. Climate Change and the Politics of Military Bases. Global Environmental Politics 18 (1):33-51.

Colgan, Jeff D., and Robert O. Keohane. 2017. The Liberal Order Is Rigged: Fix It Now or Watch It Wither. Foreign Affairs 96:36.

Drezner, Daniel. W. 2003. Bargaining, Enforcement, and Multilateral Sanctions: When Is Cooperation Counterproductive? International Organization 54 (1):73-102.

Drugmand, Dana. 2018. 2018 in Climate Liability: When a Trend Became a Wave. Available at <https:// www.climatedocket.com/2018/12/30/2018-climate-liability/>. Accessed 4 June 2020.

Farmer, J. Doyne, Cameron Hepburn, Matthew C. Ives, Thomas N. Hale, Thomas Wetzer, Penny Mealy, Ryan Rafaty, Sugandha Srivastav, and Rupert Way. 2019. Sensitive Intervention Points in the PostCarbon Transition. Science April: 132-34.

Fearon, James D. 1998. Bargaining, Enforcement, and International Cooperation. International Organization 52 (2):269-305.

Frieden, Jeffry A. 1994. International Investment and Colonial Control: A New Interpretation. International Organization 48 (4):559-93.

Friedrich, Johannes, Mengpin Ge, and Alexander Tankou. 2017. Six Charts to Understand US State Greenhouse Gas Emissions. WRI Blog. Available at <https://www.wri.org/blog/2017/08/6-charts-understand-us-stategreenhouse-gas-emissions>. Accessed 23 September 2020.

Global Carbon Project. 2019. Global Carbon Budget 2019. Earth System Science Data 11 (4):1783-838.

Global Investor Coalition on Climate Change. 2017. Letter from Global Investors to Governments of the G20 Nations. Available at <https://globalinvestorcoalition.org/wp-content/uploads/2017/07/3-July423pm-UK-time-Global-Investor-Letter-to-G20-Governments.pdf $>$. Accessed 4 June 2020.

Goldstein, Judith, and Robert Gulotty. 2021. America and the Trade Regime: What Went Wrong? International Organization 75 (2). <https://doi.org/10.1017/S002081832000065X>.

Green, Jessica F. 2014. Rethinking Private Authority: Agents and Entrepreneurs in Global Environmental Governance. Princeton University Press.

Green, Jessica F., and Thomas N. Hale. 2017. Reversing the Marginalization of Global Environmental Politics in International Relations: An Opportunity for the Discipline. PS: Political Science and Politics 50 (2):473-79.

Guber, Deborah Lynn. 2017. Partisan Cueing and Polarization in Public Opinion about Climate Change. In Oxford Research Encyclopedia of Climate Science, edited by Matthew C. Nisbet, Mike S. Schäfer, Ezra Markowitz, Jagadish Thaker, Shirley S. Ho, and Saffron O'Neill. Oxford University Press.

Hadden, Jennifer. 2015. Networks in Contention. Cambridge University Press.

Hale, Thomas. 2020. Catalytic Cooperation. Global Environmental Politics 20 (4):1-26. 
Harrison, Kathryn, and Lisa McIntosh Sundstrom, eds. 2010. Global Commons, Domestic Decisions: The Comparative Politics of Climate Change. MIT Press.

Hoffmann, Matthew J. 2011. Climate Governance at the Crossroads: Experimenting with a Global Response After Kyoto. Oxford University Press.

Hovi, Jon, Detlef F. Sprinz, and Arild Underdal. 2009. Implementing Long-Term Climate Policy: Time Inconsistency, Domestic Politics, International Anarchy. Global Environmental Politics 9 (3):20-39.

Hsueh, Lily. 2019. Corporations at a Crossroads: How Multilevel Governance Interactions Shape Participation and Effort in Private Governance Regimes. Governance. Available at $<\mathrm{http}: / /$ onlinelibrary.wiley.com/doi/abs/10.1111/gove.12406>. Accessed 21 May 2019.

Iacobuta, Gabriela, Navroz K. Dubash, Prabhat Upadhyaya, Mekdelawit Deribe, and Niklas Höhne. 2018. National Climate Change Mitigation Legislation and Targets: A Global Update. Climate Policy 18 (9): 1114-32.

Intergovernmental Panel on Climate Change. 2018. Global Warming of $1.5^{\circ} \mathrm{C}$. Available at $<\mathrm{http}: / / \mathrm{www}$. ipcc.ch/report/sr15/>. Accessed 23 September 2020.

Jinnah, Sikina, Simon Nicholson, and Jane Flegal. 2018. Toward Legitimate Governance of Solar Geoengineering Research: A Role for Sub-State Actors. Ethics, Policy and Environment 21 (3):362-81.

Kaufmann, Chaim D., and Robert A. Pape. 1999. Explaining Costly International Moral Action: Britain's Sixty-Year Campaign Against the Atlantic Slave Trade. International Organization 53 (4):631-68.

Kennard, Amanda. 2020. The Enemy of My Enemy: When Firms Support Climate Change Regulation. International Organization 74 (2):187-221.

Keohane, Robert O., and David G. Victor. 2011. The Regime Complex for Climate Change. Perspectives on Politics 9 (1):7-23.

Koubi, Vally, Tobias Böhmelt, Gabriele Spilker, and Lena Schaffer. 2018. The Determinants of Environmental Migrants' Conflict Perception. International Organization 72 (4):905-36.

Lachapelle, Erick, and Matthew Paterson. 2013. Drivers of National Climate Policy. Climate Policy 13 (5): $547-71$.

Lake, David A., Lisa Martin, and Thomas Risse. 2021. Challenges to the Liberal Order: Reflections on International Organization. International Organization 75 (2). <https://doi.org/10.1017/ S0020818320000636>.

Lake, David A., and Robert Powell. 1999. Strategic Choice and International Relations. Princeton University Press.

Lewis, Joanna I. 2014. The Rise of Renewable Energy Protectionism: Emerging Trade Conflicts and Implications for Low Carbon Development. Global Environmental Politics 14 (4):10-35.

Lowi, Theodore. 1964. American Business, Public Policy, Case-Studies, and Political Theory. World Politics 16 (4):677-715.

Mach, Katharine J., Caroline M. Kraan, Neil W. Adger, Halvard Buhaug, Marshall Burke, James Fearon, Christopher B. Field, Cullen Hendrix, Jeac-Francois Maystadt, John O'Loughlin, Philip Roessler, Jürgen Scheffran, Kenneth Schultz, and Nina von Uexkull. 2019. Climate as a Risk Factor for Armed Conflict. Nature 571 (7764):193-97.

Martin, Lisa L. 1992. Interests, Power, and Multilateralism. International Organization 46 (4):765-92.

Meckling, Jonas, Nina Kelsey, Eric Biber, and John Zysman. 2015. Winning Coalitions for Climate Policy. Science 349 (6253):1170-71.

Mehling, Michael A., Harro van Asselt, Kasturi Das, and Susanne Droege. 2018. Beat Protectionism and Emissions at a Stroke. Nature 559:321-24.

Mercure, J.-F., H. Pollitt, J.E. Viñuales, N.R. Edwards, P.B. Holden, U. Chewpreecha, P. Salas, I. Sognnaes, A. Lam and F. Knobloch. 2018. Macroeconomic Impact of Stranded Fossil Fuel Assets. Nature: Climate Change 8:588-93.

Milner, Helen V. 1997. Interests, Institutions, and Information: Domestic Politics and International Relations. Princeton University Press.

Milner, Helen V., and Dustin H. Tingley. 2011. Who Supports Global Economic Engagement? The Sources of Preferences in American Foreign Economic Policy. International Organization 65 (1):37-68. 
Newell, Peter and Matthew Paterson. 2010. Climate Capitalism: Global Warming and the Transformation of the Global Economy. Cambridge University Press.

Nordhaus, William. 2013. The Climate Casino: Risk, Uncertainty, and Economics for a Warming World. Yale University Press.

Olson, M. 1971. The Logic of Collective Action: Public Goods and the Theory of Groups. Harvard University Press.

Oreskes, Naomi, and Erik M. Conway. 2011. Merchants of Doubt: How a Handful of Scientists Obscured the Truth on Issues from Tobacco Smoke to Global Warming. Bloomsbury.

Ostrom, Elinor. 2010. Polycentric Systems for Coping with Collective Action and Global Environmental Change. Global Environmental Change 20 (4):550-57.

Pahle, Michael, Dallas Burtraw, Christian Flachsland, Nina Kelsey, Eric Biber, Joan Meckling, Ottmar Edenhofer, and John Zysman. 2018. Sequencing to Ratchet Up Climate Policy Stringency. Nature Climate Change 8:861-67.

Peters, Margaret E. 2017. Trading Barriers: Immigration and the Remaking of Globalization. Princeton University Press.

Putnam, Robert D. 1988. Diplomacy and Domestic Politics: The Logic of Two-Level Games. International Organization 42 (3):427-60.

Rickard, Stephanie J. 2018. Spending to Win: Political Institutions, Economic Geography, and Government Subsidies. Cambridge University Press.

Risse, Thomas. 2000. "Let's Argue!": Communicative Action in World Politics. International Organization 54 (1):1-39.

Setzer, Joana, and Rebecca Byrnes. 2019. Global Trends in Climate Change Litigation: 2019 Snapshot. Grantham Institute, LSE.

Stokes, Leah C. 2013. The Politics of Renewable Energy Policies: The Case of Feed-in Tariffs in Ontario, Canada. Energy Policy 56:490-500.

van Asselt, Harro. March 2017. Climate Change and Trade Policy Interaction. Working Paper, Organisation for Economic Cooperation and Development. Available at <https://doi.org/10.1787/ 18166881>. Accessed 23 September 2020.

Victor, David G. 2011. Global Warming Gridlock: Creating More Effective Strategies for Protecting the Planet. Cambridge University Press.

Wainwright, Joel, and Geoff Mann. 2018. Climate Leviathan: A Political Theory of Our Planetary Future. Verso. Wara, Michael. 2007. Is the Global Carbon Market Working? Nature 445 (7128):595-96.

Wilson, James Q. 1980. The Politics of Regulation. Basic Books.

World Bank. 2018. Groundswell: Preparing for Internal Climate Migration. World Bank. Available at $<$ https://openknowledge.worldbank.org/handle/10986/29461>. Accessed 23 September 2020.

Zürn, Michael. 2018. A Theory of Global Governance. Oxford University Press.

\section{Authors}

Jeff D. Colgan is Richard Holbrooke Associate Professor in the Department of Political Science and Watson Institute for Public and International Affairs at Brown University in Providence, Rhode Island. He can be reached at Jeff_colgan@brown.edu.

Jessica F. Green is Associate Professor in the Department of Political Science and the School of the Environment at the University of Toronto. She can be reached at jf.green@utoronto.ca.

Thomas N. Hale is Associate Professor, Public Policy in the Blavatnik School of Government at University of Oxford. He can be reached at thomas.hale@bsg.ox.ac.uk.

\section{Acknowledgments}

The authors are grateful for feedback from the editors of the special issue and the participants in the International Organization seventy-fifth anniversary issue workshops in Madison, Wisconsin, and 
Berlin, Germany, as well as participants in the Balzan climate workshops in 2019 and 2020 at the Center for Advanced Study in the Behavioral Sciences at Stanford University, the McGill Centre for International Peace and Security Studies lecture series, and the London School of Economics International Institutions, Law and Ethics series. We particularly recognize feedback from Mark Blyth, Henry Farrell, Hein Goemans, Kate Guy, Robert O. Keohane, Tom Pepinsky, Sam Rowan, and Jeremy Wallace.

\section{Key Words}

Asset revaluation; climate change; decarbonization; existential politics; liberal international order (LIO); trade

Date received: October 11, 2019; Date accepted: June 21, 2020 